\title{
Diminishing THE ATTRACTIVENESS OF TROLling: The ImPaCts of Recent Judicial ACTIVITy on Non-Practicing EnTities
}

\author{
By Holly Forsberg
}

Volume XII - Fall 2011

\begin{abstract}
The United States patent system has increasingly been faced with complications presented by a type of non-practicing entity known as patent trolls — patent owner entities that do not actively innovate, develop or manufacture patented material but instead seek to profit from patent ownership through licensing agreements and litigation. This article explores arguments on both sides of the non-practicing entity debate and evaluates perceptions of this activity as both an accessible secondary commodities market and a litigation-based business model.

Given the complexity and ever-evolving nature of various patent law claims, this article also examines the difficulties faced by legislators in attempting to solve the patent troll problem. Recent judicial activity related to patent law allowing for individually-focused, closely tailored analysis is examined with an evaluation of four recent court decisions and resulting changes to the patent system. These specific limitations placed upon the patent system are resulting in a slow but targeted effort at diminishing the power and attractiveness of patent trolling.
\end{abstract}




\section{DiminishING THE ATTRACTIVENESS OF TROLLING:

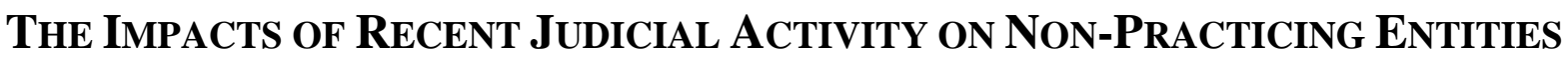

By Holly Forsberg

Volume XII - Fall 2011

Has the U.S. patent system been transformed from a system rewarding innovation with exclusive rights to a mechanism providing protection for entities that profit from attacking development? Viewed in an extreme light, possibly yes. Initially granted with the creation of the U.S. Constitution, individual patent rights and claims have been subject to significant transformation in recent years. With the ever-increasing advancements in technology and complexity of intellectual property, new issues continue to arise surrounding the enforcement of patent rights. Within the last decade, there have been significant developments in the number and sophistication of non-practicing entities (sometimes known as _patent trolls ${ }^{\natural}$ ). These entities typically do not practice their patents, but rather, base patent ownership on collecting licensing fees or pursuing litigation based on infringement.

This note will examine the complex issues associated with non-practicing entities and how legislative and judicial responses have been increasingly sought in recent years. Part I will introduce the reader to the patent troll debate and offer support both for and against the practice, demonstrating that there are strong, viable arguments for both sides of the issue. Part II will go into more detail describing the existence of non-practicing entities, a corresponding secondary commodities market and a profit-making business model that often accompanies the practice. An examination of recent federal circuit and Supreme Court decisions will demonstrate how judicially imposed limitations may affect the ability of non-practicing entities or patent trolls to 
thrive on infringement suits. Part III will offer a detailed discussion of recent judicial decisions that carry with them implications for the patent system as a whole as well as the ability of nonpracticing entities to profit from their business models.

\section{Patent Law and the Non-Practicing Entity Problem}

The Constitution states: the Congress shall have power ... to promote the Progress of . . . useful Arts, by securing for limited times to . . inventors the exclusive right to their . . . discoveries." Though the U.S. patent system has become a much more complex collection of laws and regulations since the creation of the Constitution, this explicit constitutional grant comprises the basis of today's system. In practical terms, the promise offered by the Constitution has created a long-standing tradition and expectation in the United States that creation, innovation and development will be protected and promoted. The Patent Act of 1790 (most recently revised in 1952), provided a source of legislative power that backed up this constitutional promise and expectation of protection, but modern and rapid advancements in technology continue to present new issues to the current patent system. ${ }^{2}$

In particular, one problem that has arisen is the creation of a business model where companies acquire patents or patent rights in order to generate revenue through patent licensing agreements or litigation. ${ }^{3}$ Widely known as non-practicing entities (NPEs), these entities use patents simply as a means to an end of revenue generation as opposed to legally granted tools of

\footnotetext{
${ }^{1}$ U.S. CONST., art. $1, \S 8, \mathrm{cl} .8$.

${ }^{2}$ Arthur Miller \& Michael Davis, Intellectual Property: PATENTS, TRAdEMARKS AND Copyright 8-9 (3d ed. 2000).

${ }^{3}$ Ghyo Sun Park \& Seong Don Hwang, The Rise of the NPE, Managing InTELleCtUAL Property (Dec. 1, 2010), http://www.managingip.com/Article/2740039/The-rise-of-the-NPE.html.
} 
innovation. ${ }^{4}$ Some practitioners refer to these entities as _patent trolls ${ }^{6}$, intending to convey a strong negative association with the practice. ${ }^{5}$ The use of this derogatory title has been the subject of much debate, as many see a business model approach to patent ownership as a way to create a secondary commodities market that allows for greater opportunity and liquidity for small start-up companies with limited funding. ${ }^{6}$ Yet when practiced opportunistically, NPE patentholders have the ability to legally attack entities engaging in the innovation and development of new products via lawsuits and injunctions based on infringement claims.

Whether viewed as opportunistic entities that are stalling innovation or as businesses that are creating market opportunities and simply enforcing legitimate patent claims, the impact NPE activity allowed under the patent system is an issue that is often debated as a part of patent reform. $^{7}$ Since 2007, patent reform has been debated in Congress and drafted patent reform acts have been presented every year since $2008 .^{8}$ After years of proposals, speculation and drafts, the Leahy-Smith America Invents Act (AIA) was passed by Congress and signed by President Barack Obama in September 2011. ${ }^{9}$ The passage of the AIA warrants a brief overview of the change that may most affect the ability of NPEs to operate effectively: new limitations on joinder. ${ }^{10}$ Under the AIA, parties may only be joined as defendants if both $-(1)$ the right to relief

\footnotetext{
${ }^{4} I d$.

${ }^{5}$ TJ Chiang, What is a troll patent and why are they bad?, PATENTLYO (Mar. 6, 2009), http://www.patentlyo.com/patent/2009/03/what-is-a-troll-patent-and-why-are-they-bad.html.

${ }^{6}$ Martin Lueck, Stacie Oberts \& Kimberly G. Miller, "Patent Troll”: A Self-Serving Label That Should Be Abandoned, ROBERTS, KAPLAN, MiLlER \& CIRESI, LLP (Sept. 28, 2005), http://www.rkmc.com/Patent_Troll_A Self-Serving_Label that_Should be Abandoned.htm.

${ }^{7}$ Jennifer Martinez, Tech Investors Call for Patent Reform, PoliTiCO (Nov. 18, 2010), http://www.politico.com/news/stories/1110/45295.html.

${ }^{8}$ Rick Weiss, Tackling the Challenge of Patent Reform, SCIENCE PROGRESS (Jan. 12, 2009), http://www.scienceprogress.org/2009/01/tackling-the-challenge-of-patent-reform/.

${ }^{9}$ Leahy-Smith America Invents Act, Pub. L. No. 112-29, 125 Stat. 284 (2011).

${ }^{10}$ This short caveat is meant to provide background to the reader as to very recent changes to patent law most affecting non-practicing entities. Since this legislation has been so recently enacted, it would be difficult to complete a full analysis as to how the changes will affect the patent system in practice. The focus of the remainder of this note will be on judicial activity related to the activities of NPEs and thus, mention of the AIA is primarily for the reader to gain an understanding of the type of reform that has been enacted after years of debate.
} 
is asserted against the parties jointly, severally, or in the alternative with respect to or arising out of the same transaction, occurrence, or series of transactions or occurrences relating to making, using, importing into the United States, offering for sale, or selling of the same accused product or process; and (2) questions of fact are common to all defendants or counterclaim defendants will arise in the action." ${ }^{, 11}$ With the implementation of this section, a plaintiff may no longer join alleged infringers in the same action simply based on the fact that they are accused to have infringed on the same patent. This change has been praised by many, with some noting that under the prior joinder rules, with an almost-too-casual ease, any patent owner could bring together virtually any disparate group of patent infringement defendants based upon nothing more than an allegation that each has infringed." ${ }^{\prime 2}$ This action disadvantages NPEs who have typically joined several defendants in actions on the same patent, as they will now be forced to pursue action separately on each claim unless there are both questions of fact common to all defendants and the right to relief is asserted jointly, severally, or arising out of the same action, eliminating a substantial amount of economic efficiency. ${ }^{13}$ Though this may be a step in the right direction, the full effects of the AIA remain to be seen and other changes may, in fact, end up hurting small, independent inventors and helping larger, more asset-rich corporations. ${ }^{14}$

While the implementation of the AIA is a large legislative step in the right direction, there are still a number of unanswered questions with the current patent system. Specifically related to NPEs, many seek clarification on the U.S. Patent and Trademark Office's (USPTO) position regarding the practice. ${ }^{15}$ Should this activity be allowed? How much harm are NPEs

\footnotetext{
1135 U.S.C.A. § 299(a) (2011).

${ }^{12}$ Charles Gorenstein, America Invents Act Exercises “Con-Troll” Over Patent Litigation, IPWATCHDOG (Sept. 19, 2011), http://ipwatchdog.com/2011/09/19/con-troll-over-patent-litigation/id=19279/.

${ }^{13} \mathrm{Id}$.

${ }^{14}$ See infra, note 51.

${ }^{15}$ See Weiss, supra note 8.
} 
causing to the patent system as a whole? Numerous scholars and practitioners have proffered legitimate arguments on both sides of the debate and Parts I (a) and (b) below contain common arguments presented by each side. ${ }^{16}$

\section{a. NPEs Are Abusing The Current Patent System}

Generally, individuals who believe that NPEs are abusing the current system view these entities as trolls seeking to profit primarily from legal action (whether it be through litigation, out-of-court settlements or licensing agreements). ${ }^{17}$ Often, rather than using the term _nonpracticing entity ${ }^{6}$, the term _patent troll' ${ }^{\text {is }}$ used to describe the activities of those that do not practice" their patents. ${ }^{18}$ However, it is overly broad to group all NPEs that do not actively practice their patents together into one innovation-thwarting category of patent trolls. This is because the term NPE can also be used to describe entities that choose to not actively practice their patents for legitimate, non-litigation-based reasons, such as research and development in university settings and other research institutions, as well as small start-up companies that are financially unable to practice their patents through development and production. ${ }^{19}$

These exceptions aside, however, patent trolls are generally viewed as entities that force other innovative, enterprising companies into hostage-like situations resulting in the unsavory choice between expensive litigation, costly settlements and potentially disproportionate licensing

\footnotetext{
${ }^{16}$ Compare Daniel McCurdy, Patent Trolls Erode the Foundation of the U.S. Patent System, SCIENCE PROGRESS (Jan. 12, 2009), http://www.scienceprogress.org/2009/01/patent-trolls-erode-patent-system/ (arguing that NPEs are abusing the patent system) with Lueck et al.,, supra note 6, (arguing that NPEs are simply enforcing legally-granted rights).

${ }^{17}$ Timothy Delaney, When It Comes To Patent Trolls, Decks Stacked Against Manufacturers, NAT'L L.J. (June 14, 2011), available at http://www.law.com/jsp/lawtechnologynews/PubArticleLTN.jsp?id=1202497040838\&slreturn=1.

18 Gene Quinn, In Search of a Definition for the Term “Patent Troll”, IPWATCHDOG (July 18, 2010), http://ipwatchdog.com/2010/07/18/definition-patent-troll/id=11700/.

${ }^{19} I d$.
} 
fees. ${ }^{20}$ It is argued that action pursued by such trolls is often frivolous. ${ }^{21}$ As one practitioner explained to Congress, trolls don't even need to litigate to be victorious, This unpredictable legal environment has encouraged legitimate companies threatened by patent trolls to pay large settlements as trial nears rather than risking . . their entire business. ${ }^{22}$ While the Federal Rules of Civil Procedure Rule 11(b)(1) requires that a suit is not being presented for any improper purpose, such as to harass, cause unnecessary delay, or needlessly increase the cost of litigation" and Rule 11(b)(2) states that: -elaims, defenses, and other legal contentions are warranted by existing law or by a nonfrivolous argument," Rule 11 sanctions are, historically, rarely brought up in these cases. $^{23}$

However, courts may slowly be starting to give Rule 11 claims more credence and it is possible that if more Rule 11 claims were enforced, a legitimate concern would exist for those seeking to profit from infringement litigation. ${ }^{24}$ By giving more serious consideration to Rule 11 claims, courts would be recognizing the importance of legitimate legal claims based on adequate investigation. In the past, trolls have used infringement claims to intimidate the other party into a settlement or licensing arrangement. However, an increased focus and awareness of Rule 11 claims means that more research would be required on the part of the troll to ensure that they do,

\footnotetext{
${ }^{20}$ See generally Jason Rantanen, Slaying the Troll: Litigation as an Effective Strategy Against Patent Threats, 23 SANTA Clara COMPUTER \& High TeCH. L.J. 159 (2006); Eric E. Bensen \& Danielle M. White, Using Apportionment to Rein in the Georgia-Pacific Factors, 9 COLUM. SCI. \& TECH. L. REV. 1, 1 (2008) (describing royalty awards as arbitrary` and punitive`).

${ }^{21}$ Allan Sternstein, Baseless Trademark Suits are Troublesome for Companies, INSIDE COUNSEL (July 13, 2010), http://www.insidecounsel.com/2010/07/13/baseless-trademark-suits-are-troublesome-for-companies.

${ }_{22}$ Patent Quality Improvement: Hearing Before the Subcomm. on Courts, the Internet, and Intellectual Prop., Before the H. Comm. On the Judiciary, 108th Cong. 54 (2003) (quoting David M. Simon of Intel Corporation), available at http://commdocs.house.gov/committees/judiciary/hju88545.000/hju88545_0.htm [hereinafter Patent Quality Improvement Hearing].

${ }^{23}$ FED. R. CIV. P. 11; See Gene Quinn, Rule 11 Sanctions + Exceptional Case = Bad Day for Patent Troll, IPWATCHDOG (Apr. 9, 2010), http://ipwatchdog.com/2010/04/09/rule-11-sanctions-exceptional-case-bad-day-forpatent-troll/id=10065/; Highmark, Inc. v. Allcare Health Mgmt. Sys., Inc., 706 F.Supp. 2d 713, (N.D. Tex. 2010) (It should be noted, however, that on appeal, Rule 11 sanctions were found not to be warranted, see Highmark, Inc. v. Allcare Health Mgmt. Inc., 732 F.Supp. 2d 653 (N.D. Tex. Aug. 9, 2010)).

${ }^{24}$ See Quinn, supra note 18.
} 
in fact, have a strong, legally enforceable claim. ${ }^{25}$ Ultimately, this increases the cost of claims and litigation for the troll and makes questionable_intimidation' claims less attractive. ${ }^{26}$

Licensing arrangements between trolls and entities that want use of the patent in question is one way to avoid the complexities and expense of litigation. ${ }^{27}$ While licensing agreements may be viewed favorably by both sides due to the fact that potential litigation is avoided on a particular patent or infringement issue, it has been pointed out that in some instances, fees obtained by troll entities through licensing agreements create a steady cash inflow that enable trolls to pursue litigation on other claims. ${ }^{28}$ This ultimately does not cause a decrease in the amount of litigation in the system and actually provides funding to the perpetuation of highly contentious legal action. Many argue that the bottom line argument against patent trolling is that by creating such a fear of legal action and penalty, trolling NPEs are creating a disincentive to innovate and are stifling research and development. ${ }^{29}$

In addition to simply creating a fear of lawsuits, the added costs and time required to research existing patents creates an additional burden to legitimate innovators that may ultimately deter them from producing. ${ }^{30}$ When faced with a number of unsavory options created by opportunistically navigating the complexities of the current patent system, entities may choose simply not to innovate, produce or manufacture contrary to the original purpose of the system. Importantly, this disconnect has been garnering the attention of lawmakers and increasingly the judicial system, as will be discussed below in part III.

\footnotetext{
${ }^{25}$ Matthew D. Thayne, Taming the Patent Trolls: Tactics for Dealing with a Growing Epidemic, STOEL RIVES LLP (June 9, 2008), http://www.stoel.com/showarticle.aspx?Show=2973.

${ }^{26} I d$.

${ }^{27}$ Daniel McFeely, An Argument for Restricting the Patent Rights of Those Who Misuse the U.S. Patent System to Earn Money Through Litigation, 40 ARIZ. ST. L.J. 289, 297 (2008).

${ }^{28} I d$.

${ }^{29}$ Rajkumar Vaikhari, The Effect of Patent Trolls on Litigation: A Multi-Jurisdictional Approach, 1 INDIAN J. OF INTELL. PROP. L. 64, 67 (2008), available at http://papers.ssrn.com/sol3/papers.cfm?abstract id=1320553\&rec=1\&srcabs=1314374.

${ }^{30} I d$.
} 


\section{b. NPEs Are Simply Enforcing Their Legal Rights}

Despite the arguments against the opportunistic nature of so-called patent trolls, some argue that NPEs are simply enforcing their legal rights. ${ }^{31}$ In addition to Article $1, \S 8$ of the U.S. Constitution, Title 35 of U.S. federal law provides statutory mandates on the USPTO in the granting of patents, protection of patent rights and patent cooperation. ${ }^{32}$ Under Title 35 , patent holders are granted the right to exclude others from... using...the invention" for a term beginning on the date on which the patent issues and ending 20 years from the date on which the application...was filed." ${ }^{33}$ In other words, patent holders are permitted the exclusive legal right to use their material. For some, this is where the argument ends because technically, patent enforcement by NPEs is legal. ${ }^{34}$

In addition to the legality aspect, there exist other arguments as to why the activities of NPEs should not be subject to such harsh criticism. As mentioned above, the term patent troll can be used in a context that describes non-practicing entities that are engaged in legitimate activities, such as universities and small start-up research firms that are innovating, yet simply are choosing to not yet practice patented material due to funding reasons or the need for additional research and development. ${ }^{35}$ Additionally, whether or not a patent is being practiced is irrelevant to the illegality of infringement. ${ }^{36}$ As current patent laws stand, entities pursuing

\footnotetext{
${ }^{31}$ Lueck, supra note 6.

${ }^{32}$ Patents, 35 U.S.C. $\$ \S 1-376$ (2006).

3335 U.S.C. $\S 154(a)(1),(a)(2)$ (2006).

${ }^{34}$ Lueck, supra note 6.

${ }^{35} \mathrm{Id}$.

${ }^{36}$ Though it should be noted that some have called for this to be changed. See McFeeley, supra note 21, at 310-12.
} 
legal action based on infringement are completely within their rights as a patent owner, regardless of how they choose to use their patent rights. ${ }^{37}$

Legitimate activities that often involve the non-use of patents include universities and other large research institutions. These entities often purchase patents that end up being used for the purpose of long-term research rather than any type of immediate production or development. ${ }^{38}$ Additionally, universities typically are not, nor are they primarily intended to be, product-manufacturing entities. ${ }^{39}$ If broad measures such as an affirmative defense for failure to practice a patent were put into place, many legitimate NPEs would likely be directly adversely affected. Though such measures would be based in an effort to help disable the activities of trolls, there would be many instances in which small entities and start-up firms would be penalized for being unable (financially or otherwise) or unwilling (for a myriad of reasons) to actively practice" their patents. While this system could possibly help to disable the effective business model of the patent troll, consequences would be the resulting creation of large barriers for research entities and small, asset-lean firms. This type of change would, in effect, be exchanging the stifling of innovation by trolls through litigation for the stifling of innovation by law through enhanced barriers for researchers and innovators and the superfluous policing of the innovative process.

\footnotetext{
${ }^{37}$ Lueck, supra note 6. Though non-use of patent rights is not the subject of this note, some have called for the creation of an affirmative defense for failure to practice as a possible solution to the patent troll problem (though it merits mention that this is not the current state of the law and as such, the remainder of the note will discuss patent law as it presently stands). McFeeley, supra note 27, at 310-12.

${ }^{38}$ Lueck, supra note 6.

${ }^{39}$ Mark A. Lemley, Are Universities Patent Trolls?, 18 FordHAm InTELl. Prop. Media \& ENT. L J. 611, 615 (2008).
} 


\section{Creation of a Secondary Commodities Market vs. Litigation-Based Business Model}

Despite arguments against the activities of entities that neither practice their patents nor actively participate in any innovation, there is an economic theory that supports the activities of NPEs. Whether viewed as beneficial to small companies or harmful to innovation, the activities of NPEs may be examined from two points of view: (1) these activities have resulted in the creation of a secondary commodities market that provides opportunity for small entities with limited financial resources or (2) these entities have acted opportunistically to the detriment of innovation in creating a litigation-based business model that strives only to profit from legal action based on unused patents and provides no benefit to the market or society as a whole.

Acacia Research, known to many in the industry as a patent troll, states its business activities as gaining capital from its investors to acquire, develop and enforce patented technologies."40 These patented technologies ‘ - perating subsidies generate license fee revenues and related cash flows from the granting of licenses for the use of patented technologies.",41 While this may be viewed as legitimate business activity and not unlike the activities of intermediaries in a number of different industries, ${ }^{42}$ the monopolistic ownership of ideas related to exclusive patent rights distinguishes patent-based business models. ${ }^{43}$ One key distinction that needs to be made is whether the business model is made for the facilitation, service and corresponding profit through the use of innovation, development and manufacturing; or made for

\footnotetext{
${ }^{40}$ Acacia Research Corporation, Form 10-K (Fiscal Year 2009), available at http://yahoo.brand.edgaronline.com/displayfilinginfo.aspx?FilingID $=7081542-12042$ $40402 \&$ type $=$ sect $\&$ TabInde $x=2 \&$ companyid $=1231 \& p p u=\% 252$ Default. asp $x \% 253$ fcompanyid $\% 253 \mathrm{~d} 1231 \% 2526 \mathrm{a}$ $\mathrm{mp} \% 253$ bformtypeID $\% 253 \mathrm{~d} 7$.

${ }^{41} I d$.

${ }^{42}$ For example, activities can loosely be likened to those of wholesalers in a business context as well as car dealers, stockbrokers and real estate agents.

${ }^{43}$ Patent Trolls and Patent Enforcement Rights, PATENTS R Us, http://www.patentsr.us/articles/patent-trolls-patentenforcement.html (last visited Oct. 17, 2011).
} 
facilitation, service and profit through litigation (or using Acacia‘s language, -enforcement”). The latter is what many opponents of non-practicing entities view as the problem. The right and ability to prohibit others from using patented ideas, technologies and techniques to serve the public good and profit from such enforcement are certainly contrary to the Constitution's aim to promote the Progress of ... useful Arts.. ${ }^{44}$

Despite widespread criticism of the practice, with some characterizing the patent troll business model as a simple and effective source of illegitimate profit irrespective of the quality of the patent," the patent troll business model focused on litigation is a business that is alive and well. ${ }^{45}$ According to a 2010 PricewaterhouseCoopers (PwC) study, -damage awards for NPEs have averaged more than triple those for practicing entities since 2001.,46 This serves as evidence that those regularly pursuing patent litigation are becoming increasingly sophisticated at their art and this disparity between NPEs and practicing entities is continuing to grow. The same PwC study found that between 1995 and 2001, median damage awards granted to NPEs versus practicing entities were $\$ 5.2$ million to $\$ 6.3$ million, respectively, and this disparity grew between 2002 and 2009 as the median NPE damage award rose to $\$ 12.9$ million while the median award for practicing entities fell to $\$ 3.9$ million. ${ }^{47}$ These types of statistics often gain attention and provide strong support to the widespread call for a solution to the patent troll problem.

What about those entities involved in helping facilitate innovation for small start-up companies? In terms of non-practicing entities overall, a secondary licensing market helps facilitate business and innovation capabilities to small or specialized operations that do not have

\footnotetext{
${ }^{44}$ U.S. CONST., art. $1, \S 8$, cl. 8.

${ }^{45}$ Patent Quality Improvement Hearing, supra note 22, at 53.

${ }^{46} 2010$ Patent Litigation Study: The Continued Evolution of Patent Damages Law, PrICEWATERHOUSECOOPERS available at $\mathrm{http}: / / \mathrm{www} . \mathrm{pwc} . c 0 \mathrm{~m} / \mathrm{us} / \mathrm{en} /$ forensic-services/publications/assets/2010-patent-litigation-study.pdf, at 5 . ${ }^{47} I d$.
} 
the resources, expertise or need for exclusive patent ownership. Likening the practice of a patent market intermediary to that of a securities dealer supplying capital markets, it has been argued that patent market intermediaries facilitate efficiency by increasing patent liquidity. ${ }^{48}$

For small businesses or individual inventors that may not have the capital to fully develop their products, the ability to patent an idea and license it out frees up capital so the small entity may continue its work while society as a whole benefits from the innovation. Under this idea, it has even been proposed that the term _pant dealer' be coined when referring to non-practicing patent owners engaged in licensing. ${ }^{49}$ Ideally, under a system of patent dealers businesses would be able to make better use of limited resources and focus on specializations and their comparative advantage, whether it lies in ideas and innovation or development and production. Evaluated in terms of basic economics, a system that allows for and eases the facilitation of licensing agreements encourages businesses to specialize which results in an advantage to society. ${ }^{50}$

Issues arise in finding the delicate balance between curbing the abilities of those taking advantage of a secondary commodities market through litigation and promoting the activities of those who use the secondary commodities market as a tool to assist in innovation development. However, if regulations were imposed seeking to control opportunistic usage of patent markets, these changes may be unwittingly detrimental to small companies (as many fear will be the result of recent patent reform). ${ }^{51}$ There are a number of valid concerns raised on both sides of the NPE

\footnotetext{
${ }^{48}$ James F. McDonough III, The Myth of the Patent Troll: An Alternative View of the Function of Patent Dealers in an Idea Economy, 56 EMORY L.J. 189, 216 (2006).

${ }^{49} I d$. at 201.

${ }^{50}$ Comparative Advantage, LIBRARY OF ECONOMICS AND LIBERTY, http://www.econlib.org/library/Topics/Details/comparativeadvantage.html (last visited Jan. 26, 2011).

${ }^{51}$ Deborah Sweeney, New Patent Law and its Impact on Small Businesses, BUSINESS INSIDER (Sept. 26, 2011), http://www.businessinsider.com/new-patent-law-and-its-impact-on-small-businesses-2011-9. As an example, many feel that the recent changes to a first to file system is detrimental to small, independent inventors or innovators who are unable to quickly or immediately file a patent application due to limited time and assets. Brett Trout, Senate
} 
debate and it is often argued that sweeping legislative reform in an effort to combat the patent troll issue may result in dangerous unintended consequences for small companies and research institutions in their activities as NPEs. ${ }^{52}$

\section{Judicial Decisions Changing Patent Law}

Recognizing increasing frustrations with the patent system as a whole, the judicial system has begun to hear more patent cases in an attempt to settle issues that are having a large impact on the system. Due to the nature and quick evolution of intellectual property and technology, there are an ever-increasing number of issues and correspondingly, cases being decided to answer the growing number of questions facing patent litigation. This section contains examples

of recent judicial decisions that may, collectively, have a substantial impact on the practice of trolls and their ability to operate as effectively as they have in the past. By narrowly addressing issues presented by specific instances, this judicial authority is slowly chipping away at the power of patent trolls with arguably less adverse impact on legitimate non-practicing entities than widespread patent reform.

\section{a. MedImmune v. Genetech}

In MedImmune v. Genetech, patent validity was the focus. ${ }^{53}$ The question to be decided by the Supreme Court was whether the Declaratory Judgment Act requires a patent licensee to

Passes Bill Favoring Corporations Over Inventors, BlawgIT (Mar. 10, 2011), $\mathrm{http} / /$ blawgit.com/2011/03/10/senate-passes-bill-favoring-corporations-over-inventors/.

${ }^{52}$ Damien Geradin, Anne Layne-Farrar \& A. Jorge Padilla, Elves or Trolls? The Role of Non-Practicing Patent Owners in the Innovation Economy, TILEC Discussion Paper No. 2008-018 (2008) at 22, available at http://ssrn.com/abstract=1136086. 
terminate or be in breach of its license agreement before it can seek a declaratory judgment that the underlying patent is invalid, unenforceable, or not infringed." ${ }^{54}$ More simply, the issue was whether a licensee, in choosing not to pay license fees on a patent it feels is invalid, must first breach its contract by not paying the fees while seeking a declaratory judgment on patent validity. A problem arose because by ceasing to pay licensing fees, the licensee (MedImmune) was making itself vulnerable to breach of contract suits by the licensor (Genetech). In this case, MedImmune felt that it was under no obligation under a license agreement with Genetech to pay royalties on a patent that MedImmune believed to be invalid. ${ }^{55}$ The Supreme Court reasoned that MedImmune should not have to bear the risk of possible legal action and resulting financial harm in order to assert its rights (their beliefs and claim that the patent was valid). ${ }^{56}$ This decision provides a great advantage to licensees, as they are now able to challenge the validity of a patent without exposing themselves to the liability of breach of contract claims. ${ }^{57}$

The MedImmune decision has received praise accompanied by an increase in licensee`s rights but is also faced with criticism. With the ruling, the underlying certainty of patent ownership and licensing agreements has been called into question. ${ }^{58}$ By creating an avenue of uncertainty related to licensing agreements, it is quite possible that the efficiency and attractiveness of such arrangements will be somewhat decreased. Some argue that this uncertainty may result in the creation of a barrier to an efficient system of technology transfer,

\footnotetext{
${ }^{53}$ Medimmune, Inc. v. Genetech, Inc., 549 U.S. 118 (2007). Patent validity is often an issue raised by defendants and will be further explored infra in Part III (d).

${ }^{54} I d$. at $120-21$.

${ }^{55} I d$. at 124.

${ }^{56} I d$.

${ }^{57}$ Dennis Fernandez \& Brian J. Bensch, The Impact of MedImmune v. Genetech, IPFronTLINE (May 22, 2007), http://www.ipfrontline.com/depts/article.aspx?id=15101\&deptid=3.

${ }^{58} I d$.
} 
thus increasing transaction costs. ${ }^{59}$ It has also been argued that this inefficiency may result in increased fees for drafting and negotiating licenses as well as increased likelihood of litigation. ${ }^{60}$ Though Justice Thomas dissented in MedImmune, stating: By holding that contractual obligations are sufficiently coercive to allow a party to bring a declaratory judgment action, the majority has given every patent licensee a cause of action and a free pass," and that the decision eontains no limiting principle whatsoever," the Court decision was an 8-1 majority. ${ }^{61}$

The fact that licensors (typically in a troll scenario, the NPE) are now faced with an additional level of danger will likely have some impact on the practice of NPEs. The result of the decision is that licensors now have less leverage due to the fact that they are unable to rely on a breach of contract claim as a counter-attack to a question of patent validity. ${ }^{62}$ By increasing the possibility of legal action and raising the overall cost of licensing agreements for both parties, the business of licensing agreements becomes a bit more risky and overall less economically attractive.

\section{b. eBay v. MercExchange}

Perhaps an even more significant development in creating barriers to the activities of trolls is the 2006 Supreme Court decision of eBay v. MercExchange. ${ }^{63}$ In eBay, the question to be answered was: Under the Patent Act, should a permanent injunction always be issued when a patent has been violated, absent exceptional circumstances? ${ }^{64}$ The Court decided unanimously

\footnotetext{
${ }^{59}$ Peter Jay, Removing Incentives for Technology Transfer: Medimmune v. Genetech, 5 BUFF. INTELL. PROP. L.J. 69, 81 (2007).

${ }^{60} \mathrm{Id}$. at 82 .

${ }^{61}$ MedImmune, 549 U.S. at 146 (Thomas, J., dissenting).

${ }^{62}$ Jennifer L. Collins \& Michael A. Cicero, The Impact of MedImmune Upon Both Licensing and Litigation, 89 J. PAT. \& TRADEMARK OFF. SOC'Y 748, 751 (2007).

63 eBay, Inc. v. MercExchange, Inc., 547 U.S. 388 (2006).

${ }^{64}$ eBay v. MercExchange, OYEZ, http://www.oyez.org/cases/2000-2009/2005/2005_05_130 (last visited Jan. 26, 2011).
} 
that no, a permanent injunction should not always be issued but instead, the plaintiff seeking the injunction must satisfy a four-part test. ${ }^{65}$ In order to be granted a permanent injunction, a plaintiff now must prove that $(1)$ it has suffered an irreparable injury; (2) that remedies available at law... are inadequate to compensate for that injury; (3) that, considering the balance of hardships between the plaintiff and the defendant, a remedy in equity is not warranted; and (4) that the public interest would not be disserved by a permanent injunction." ${ }^{\text {"66 }}$ In eliminating the automatic injunction, the Court closely examined the language of the Patent Act, noting that the language provides that injunctions - may" be issued. ${ }^{67}$

This decision affects the ability of NPEs to operate efficiently, and in his concurrence Justice Kennedy explicitly touched on the existence of such entities: An industry has developed in which firms use patents not as a basis for producing and selling goods but, instead, primarily for obtaining licensing fees... For these firms, an injunction, and the potentially serious sanctions arising from its violation, can be employed as a bargaining tool to charge exorbitant fees to companies that seek to buy licenses to practice the patent." ${ }^{68}$ Justice Kennedy, identifying the business model of patent ownership and licensing agreements concluded that when the threat of an injunction is employed simply for undue leverage in negotiations, legal damages may well be sufficient to compensate for the infringement and an injunction may not serve the public interest.",69

Justice Kennedy's observation has quite possibly the largest limiting effect on the ability of patent trolls and NPEs using their patents opportunistically by declaring that in many of these instances, injunctions are not only necessary, but harm the public interest. With those few

\footnotetext{
${ }^{65}$ eBay, 547 U.S. at 391.

${ }^{66} \mathrm{Id}$.

${ }^{67} I d$. at 392.

${ }^{68}$ Id. at 396 (Kennedy, J., concurring).

${ }^{69} \mathrm{Id}$.
} 
sentences, Justice Kennedy was able to remove some of the leverage from which patent trolls have, historically, received benefit. This distinction of harming the public interest is important because it allows for judicial discretion to help distinguish between what entity may be classified as a troll and what may be classified as a legitimate, innovative NPE. The concurrence of Justice Kennedy has been cited in additional cases to identify situations where the patent holder was operating in a profit-seeking manner as an NPE. ${ }^{70}$ Judging those NPEs that hinder the public interest with increasing harshness, a district court case from the Eastern District of Texas has gone so far as to effectively destroy the NPE`s right to exclude others from using the patented material. ${ }^{71}$

Though the call for patent reform has been widespread, Justice Kennedy points out the direction that the patent system seems to be moving as of recent:

The equitable discretion over injunctions, granted by the Patent Act, is well suited to allow courts to adapt to the rapid technological and legal developments in the patent system. For these reasons, it should be recognized that district courts must determine whether past practice fits the circumstances of the cases before them." 72

Here, Justice Kennedy's statements seem to identify the fact that judicial remedies are an effective means to create change due to the ever-developing nature of technology and patent issues. Given the boilerplate application of Congressional action, judicial remedies seem to be particularly well suited to the intricacies of non-practicing entity issues. Being able to weigh the

\footnotetext{
${ }^{70}$ z4 Techs., Inc. v. Microsoft Corp., 434 F.Supp. 2d 437, 441 (E.D. Tex. 2006); Paice L.L.C. v. Toyota Motor Corp., No. 2:04-CV-211-DF, 2006 WL 2385139, at*4 (E.D. Tex. Aug. 16, 2006); Miranda Jones, Permanent Injunction, A Remedy By Any Other Name is Patently Not The Same: How eBay v. MercExchange Affects the Patent Right of Non-Practicing Entities, 14 GEO. MASON L. REV. 1035, 1037 (2007).

${ }^{71}$ Finisar Corp v. DIRECTV Group, Inc., No. 1:05-CV-264, 2006 WL 2709206 (E.D. Tex. Sept. 1, 2006) (Though parts of this decision were overturned on appeal, the initial verdict may be used to illustrate increasing harshness against an entity that does not practice its patent); Yixin H. Tang, The Future of Patent Enforcement After eBay $v$. MercExchange, 20 HARV. J.L. \& TECH, 235, 249 (2006).

72 eBay, 547 U.S. at 397 (Kennedy, J., concurring).
} 
importance of factors such as benefits to the public interest, judicial decisions are increasingly attempting to remedy problems presented by the current patent system.

Despite the benefits, the eBay decision is not without controversy. Since the Supreme Court did not offer any guidance as to how to apply the four-factor test, it has been noted that district courts may apply the test differently resulting in incongruent decisions by district. ${ }^{73}$ It is also suggested that this issue may lead patent trolls to forum shop for districts that have applied the four-factor test in a way that is more favorable to an entity that does not practice its patents. ${ }^{74}$ Additionally, it has been noted that since injunctions have been applied inconsistently in different district courts and alternative remedies have attempted and failed, ultimately patent trolls will just simply adjust the way they run their businesses. ${ }^{75}$ Even with criticisms, the eBay decision marks a milestone in the leveraging power between a potential opportunistic troll and a legitimate business and provides an additional defense to the legitimate business in its fight against injunctions.

\section{c. Uniloc v. Microsoft}

The recent decision of Uniloc v. Microsoft further chips away at the power and attractiveness of patent trolling activities by significantly changing the way will damages be determined. ${ }^{76}$ Courts have used a generally accepted twenty-five percent standard to approximate the reasonable royalty rate that the manufacturer of the patented product would be

\footnotetext{
${ }^{73}$ Damian Myers, Reeling in the Patent Troll: Was ebay v. MerExchange Enough?, 14 J. INTELL. PROP. L. 333,348 (2007).

${ }^{74}$ Id. at $348,351$.

${ }^{75}$ Leslie T. Grab, Equitable Concerns of eBay v. MercExchange: Did the Supreme Court Successfully Balance Patent Protection Against Patent Trolls?, 8 N.C. J.L. \& TECH. 81, 103-105, 109 (2006).

${ }^{76}$ Uniloc USA, Inc. v. Microsoft Corp., 632 F.3d 1292 (Fed. Cir. 2011), reh'g denied (Mar. 22, 2011).
} 
willing to offer to pay to the patentee during a hypothetical negotiation." by dividing expected profits by expected net sales, resulting in a profit rate that is then multiplied by twenty-five percent to reach a baseline royalty rate. ${ }^{78}$ However, it is noted that this rule fails to account for the unique relationship between the patent and the accused product" resulting in a baseline royalty rate that does not accurately reflect the results of a hypothetical negotiation between the parties. ${ }^{79}$ Thus, the court decided that the twenty-five percent general rule was a fundamentally flawed tool for determining a baseline royalty rate" which had been perpetuated simply because of its widespread acceptance. ${ }^{80}$ With this reasoning, it was determined that evidence relying on the use of the twenty-five percent general rule be considered inadmissible. ${ }^{81}$ In its explanation, the court described the twenty-five percent rule as -arbitrary" and that such a rule is deemed to taint the jury's damages calculation." ${ }^{82}$ Now, rather than being able to rely upon a generous, essentially automatic twenty-five percent damage calculation, NPEs may be more weary of the fact that -enclusions made correspond to the facts of the case, and that the evidentiary burdens are met." ${ }^{33}$

Today, instead of relying on an industry-accepted twenty-five percent rule of thumb, the patentee must establish a basis using factual analysis and fair market value. ${ }^{84}$ Parties involved have stated that the decision is a -strong validation of the value of the patent" and that it is an important and helpful opinion with respect to the law of damages and it may signal the end to

${ }^{77}$ Id. at 1312 .

${ }^{78} \mathrm{Id}$.

${ }^{79}$ Id. at 1313 .

${ }^{80} \mathrm{Id}$. at 1315.

${ }^{81} \mathrm{Id}$.

${ }^{82}$ Uniloc, 632 F.3d at 1318.

${ }^{83}$ Jason Miller, Patent Litigants-25\% Rule is Dead!, The NaTIONAL LaW REVIEW (Jan. 11, 2011), available at http://www.natlawreview.com/article/patent-litigants-25-rule-dead.

${ }^{84}$ Adrian Lurrsen, Uniloc v. Microsoft: What Lawyers are Saying, JDSUPRA (Jan. 20, 2011), http://scoop.jdsupra.com/2011/01/articles/legal-research/uniloc-v-microsoft-what-lawyers-are-saying/. 
unreasonable and outsized damages awards based on faulty methodology." ${ }^{\text {} 85}$ This decision should cause patent trolls to be somewhat cautious. It places an additional hurdle in an attempt to gain high licensing fees that will be protected by the courts. The court in Uniloc also expressed some respect and favor for the activities of the licensee: The licensee should retain a majority of the profits, because it has undertaken substantial development, operational and commercialization risks, contributed other technology/IP and/or brought to bear its own development, operational and commercialization contributions. ${ }^{\prime 86}$ This statement along with the ultimate decision in Uniloc further evidences the court's preference for giving the benefit to the entity that actually _practices' the patent, and rightly so if one bases an opinion on the traditional foundations of the U.S. patent system. Numerous elements of Uniloc weigh in favor of the active user of the patent, which raises concern and presents additional hazards to the practice of trolling. Rather than imposing complex legislation, the Uniloc decision simply chips away at the attractiveness and financial benefits of trolling by restoring ideas of equity that support the innovator and promote the _useful arts' protected by the Constitution.

\section{d. Microsoft Corp. v. i4i Ltd. Partnership}

The Supreme Court recently heard the case of Microsoft Corp. v. i4i Ltd. Partnership to determine what standard of proof should be used to challenge a patent's validity, either clear and

\footnotetext{
${ }^{85}$ Susan Decker, Microsoft Loses Court Ruling in Uniloc Patent Case, Bloomberg, (Jan. 4, 2011), available at http://www.bloomberg.com/news/2011-01-04/microsoft-loses-appeal-in-388-million-uniloc-verdict-update1-.html. ${ }^{86}$ Uniloc, 632 F.3d at 1313 (quoting Robert Goldscheider, John Jarosz \& Carla Mulhern, Use of the 25 Per Cent Rule in Valuing IP, 37 les Nouvelles 123, 124 (Dec. 2002), available at http://www.bu.edu/otd/files/2009/11/goldscheider-25-percent-rule.pdf).
} 
convincing evidence or some lesser standard. ${ }^{87}$ It was the contention of Microsoft that the standard of proof should be lowered from clear and convincing to a less demanding standard when there is additional evidence (referred to as _pior art') not considered by the USPTO in initially granting the patent. ${ }^{88}$ Section 282 of Title 35 of the U.S. Code requires that the burden of establishing invalidity of a patent or any claim thereof shall rest on the party asserting such invalidity," but this section does not establish the standard of proof to satisfy the evidentiary burden. $^{89}$

Microsoft argued since the statute is silent on the evidentiary burden, an applicable standard should be based on a preponderance of evidence (citing the decision of Grogan v. Garner). ${ }^{90}$ Grogan stated that: -silence is inconsistent with the view that Congress intended to require a special, heightened standard of proof." ${ }^{\prime 11}$ i $4 \mathrm{i}^{\text {‘s }}$ contention that there should be a very high burden to prove invalidity was supported by the 1934 Supreme Court case Radio Corp. $v$. Radio Engineering Labs., Inc. ${ }^{92}$ There, the Court held that there is a presumption of patent validity that may not be -øverthrown except by clear and convincing evidence." ${ }^{93}$ The Radio Corp. opinion considers the preponderance of evidence standard but ultimately describes it as -dubious". ${ }^{94}$ This issue is further complicated by the fact that prior to the creation of the federal

\footnotetext{
${ }^{87}$ Microsoft Corp. v. i4i Ltd. P‘ship, 131 S. Ct. 2238, 180 L. Ed. 131 (2011); Microsoft v. i4i Limited Partnership, SCOTUSBLOG, http://www.scotusblog.com/case-files/cases/microsoft-v-i4i-limited-partnership/ (last visited Feb. 24, 2011).

${ }^{88}$ Greg Stohr, Microsoft Gets U.S. Supreme Court Hearing in i4i Case Over Word Software, BlOOMBERG (Nov. 29, 2010), available at $\mathrm{http}: / / \mathrm{www} . b l o o m b e r g . c o m / n e w s / 2010-11-29 /$ microsoft-gets-u-s-supreme-court-hearing-in-caseagainst-i4i-of-toronto.html.

${ }^{89} 35$ U.S.C. $\$ 282(2011)$.

${ }^{90} 498$ U.S. 279 (1991).

${ }^{91} \mathrm{Id}$. at 286.

92293 U.S. 1 (1934).

${ }^{93} \mathrm{Id}$. at 2 .

${ }^{94} I d$. at 8 (-an infringer who assails the validity of a patent fair upon its face bears a heavy burden of persuasion, and fails unless his evidence has more than a dubious preponderance").
} 
circuit court system in 1982, the courts were split on their interpretation of the issue and a presumption of validity was not uniform throughout the system. ${ }^{95}$

If the Court sided with the arguments of Microsoft, the result would have been a fairly complicated and confusing application of different standards of proof for prior art considered by the USPTO (requiring clear and convincing evidence to rebut the presumption of validity) and new evidence of prior art not considered by the USPTO (requiring a only preponderance of evidence standard to rebut presumption of validity). ${ }^{96}$ Despite the complexity of a pro-Microsoft decision, Microsoft's claims were supported by several amici, arguing for the lower _preponderance' evidentiary standard when prior art in question was not examined, for the reason that there should not be deference to a decision based on lack of knowledge or awareness. ${ }^{97}$ Offering additional support for the presented arguments, Microsoft's petition for certiorari attacked the adequacy of the patent system by noting the recent surge of patent implications and strain on the system as well as citing -significant information asymmetries" leading to an increasingly large number of mistakes, some of them glaring." 98

However, i4i's argument against changing the evidentiary standard was focused primarily on preserving benefit to the public interest and stated that a heightened burden benefits the public by increasing inventors' ${ }^{6}$ incentive to commit the resources required for innovation and

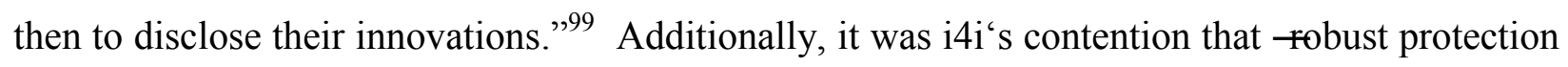

\footnotetext{
${ }^{95}$ Firm Publication: Microsoft Corp. v. i4i Ltd. P'ship, LATHAM \& WATKINS, LlP (Dec. 15, 2010), http://www.lw.com/Resources.aspx?page=FirmPublicationDetail\&publication=3853.

${ }^{96}$ Gene Quinn, Supreme Court to Hear Microsoft v. i4i Argument April 18, 2011, IPWATCHDOG (Feb. 13, 2011), http://ipwatchdog.com/2011/02/13/supreme-court-microsoft-i4i-april-18-argument/id=15298/.

${ }^{97}$ Clement S. Roberts, Microsoft v. i4i: Amici Make Strong Argument for Supreme Court Review of Patent Invalidity Standard, PATENT LAW PraCtice CenTER (Oct. 5, 2010), http://patentlawcenter.pli.edu/2010/10/05/microsoft-v-i4iamici-make-strong-argument-for-supreme-court-review-of-patent-invalidity-standard/.

${ }_{98}$ Brief of Petitioner, Microsoft Corp. v. i4i Ltd. P‘Ship, 131 S. Ct. 647 (2010) (No. 10-290), 2010 WL 3413088 at $* 19-20$.

${ }^{99}$ Brief in Opposition, Microsoft Corp. v. I4i Ltd. P‘Ship, 131, S.Ct. 647 (2010) (No. 10-290), 2010 WL 4314336 at *3.
} 
against erroneous invalidation of patents recognizes and protects the enormous resources that go into the innovation process, and gives inventors a strong incentive to invest those resources and then disclose their innovations." ${ }^{\prime 100}$ By stating that -adopting a lower standard of proof for any piece of prior art not specifically cited by the PTO would further burden already-overtaxed patent examiners," i4i presented the parade of horribles related to the issue of examination and questioning related to potentially irrelevant prior art, resulting in $-\mathrm{a}$ more expensive application process (a particular onus for individuals and other small innovators) and a sharp increase in application processing time." 101 Again focusing on the basis of the patent system, i4i stated: - Nkrosoft's argument ignored the public benefit provided by the clear-and-convincing standard," a standard which gives inventors a greater incentive to engage in innovation . . . allowing the public to enjoy the fruits of those inventions."

Although both sides presented legitimate arguments on points of law, the Court was tasked with both staying in line with recent decisions and developments and being mindful of the broader responsibility of the providing protection for public interest related to patents. ${ }^{103}$ On June 9, 2011, the Supreme Court unanimously sided with i4i, deciding that an invalidity defense would have to be proven by clear and convincing evidence. ${ }^{104}$ Justice Sotomayor noted that applying Microsoft's proposed variable standard of proof would be \#nusual and impractical"

\footnotetext{
${ }^{100} I d$. at $* 18$.

${ }^{101} I d$. at $* 22$.

${ }^{102} I d$. at $* 26$.

${ }^{103}$ It is interesting to note the effect that previously discussed cases will have on future cases dealing with patent issues. Uniloc v. Microsoft actually cites to the initial $i 4 i v$. Microsoft case and its use of the 25 percent rule. In Uniloc, the court states that $[\mathrm{c}$ ]ourts have invariably admitted evidence based on the $25 \%$ rule, largely in reliance on its widespread acceptance" and goes on to quote the initial $i 4 i$ decision, stating: [i $4 i^{\prime}$ 's expert] testified that it was customary within his field to apply a $25 \%$ rule of thumb '... Thus, considering the foundation laid by [i4i's expert's] testimony, his application of the $25 \%$ rule was relevant and appropriately considered". Based on Uniloc's decision, it is now possible that when other courts are faced with a similar issue regarding the determination of appropriate royalty rates, this recent Fifth Circuit decision for will provide guidance.

${ }^{104}$ Microsoft Corp., 131 S. Ct. at 2240.
} 
and stated that an -xaminer is under no duty to cite every reference he considers." 105 Though the decision noted that new evidence of prior unexamined art perhaps should carry more weight than previously examined art, new evidence is simply not strong enough to change the burden of proof for invalidity. ${ }^{106}$

Some feel the Court's decision in favor of $i 4 \mathrm{i}$ is a small victory for patent trolls, as a lowered evidentiary standard would have created encouragement as well as eased the process of challenging patents of questionable validity. ${ }^{107}$ Thus, to a certain extent, patents currently held by trolling NPEs have maintained the previous level of protection. ${ }^{108}$ However, it is important to keep in mind that by lowering the evidentiary standard to preponderance of evidence, the value and certainty associated with patent ownership would have been diminished by making determinations of patent invalidity easier to obtain for all patents, those owned by both trolls and legitimate practicing entities and innovators. ${ }^{109}$ One benefit obtained by defendants as a result of the Microsoft decision is that juries are now able to be made explicitly aware they are considering evidence that the PTO had no opportunity to evaluate before granting the patent" and to -evaluate whether the evidence before it is materially new, and if so, to consider that fact when determining whether an invalidity defense has been proved by clear and convincing evidence." 110

\footnotetext{
${ }^{105}$ Id. at 2250,2250 n. 10.

106 Id. at 2250 .

107 Patent Validity: Supreme Court Maintains Status Quo, Nolo (June 10, 2011), http://www.nolo.com/legalupdate/patent-invalidity-supreme-court-microsoft-46937.html; Nancy Gohring, Supreme Court Ruling Seen as a Win for Patent Trolls, PCWORLD (June 9, 2011), http://www.pcworld.com/article/229968/supreme_court_ruling_seen_as_a_win_for_patent_trolls.html. ${ }^{108}$ Id.

${ }^{109}$ Microsoft v. $i 4 i$-Awaiting a Burdensome Decision by the Supreme Court, PRACTISING LAW INSTITUTE (May 17, 2011, 3:12 pm), http://patentlawcenter.pli.edu/2011/05/17/microsoft-v-i4i---awaiting-a-burdensome-decision-bythe-supreme-court/.

${ }^{110}$ Microsoft Corp., 131 S. Ct. at 2251.
} 
With this decision, the Court had the ability to explicitly take into account the implications on small innovators and legitimate NPEs, however this issue was largely avoided with a few small exceptions focused on the foundational basis of the patent system. ${ }^{111}$ The broad issue of difficulties faced by the present patent system was avoided and even deferred to legislators as it was succinctly stated that over time, -Congress has amended the patent laws to account for concerns about bad' patents, including by expanding the reexamination process." ${ }^{112}$ However, Justice Breyer acknowledged the Court's responsibility is to preserve the original goals of the patent system noting, By preventing the elear and convincing" standard from roaming outside its fact-related reservation, courts can increase the likelihood that discoveries or inventions will not receive legal protection where none is due." 113

In his concurring opinion, Justice Thomas supported the Court's decision but clearly remained somewhat skeptical that Congress intended such a clear, codified standard of proof. ${ }^{114}$ This may suggest that members of the Court may be willing to review holes and ambiguities in the patent system in the future. Although ultimately the Supreme Court did not fully take advantage of the opportunity to speak to the potential differences of patent validity between trolling entities and legitimate non-practicing entities that foster technological innovation, the decision is a small step in the right direction and the fact that the Court generally recognized the importance of patent issues is encouraging.

\footnotetext{
${ }^{111}$ Mark Hachman, Supreme Court to Hear Microsoft, i4i Dispute, PCMAG.COM (Nov. 30, 2010), available at http://www.pcmag.com/article2/0,2817,2373620,00.asp.

${ }_{112}$ Microsoft Corp., 131 S. Ct. at 2252.

${ }^{113}$ Id. at 2253 (Breyer, J., concurring).

${ }^{114} I d$. at 2253-54 (Thomas, J., concurring).
} 


\section{Conclusion}

The patent law system continually faces novel and difficult questions due to the everincreasing sophistication of technological advancement and invention. Recognizing the opportunity for profit, non-practicing entities have entered the patent -market" in an attempt to gain financial benefit through litigation and licensing agreements, though these actions are often contrary to the foundational basis of the United States patent law system. In an attempt to combat the stifling of innovation and after many years of debate and proposed reform, Congress passed the Leahy-Smith America Invents Act in an effort to help reform the overburdened U.S. patent system. However, many feel that the AIA did not do enough to fight the activities of opportunistic NPEs and some fear the legislative change may result in harmful, unintended consequences.

Because of the close, careful tailoring additional patent reform would require, growing judicial interest and activity in the area of patent law currently seems to be an effective means to address the troll problem. Through specific limitations and burdens placed upon NPEs resulting from decisions based on real-life situations, problems occurring in practice are being addressed. Notably, the Supreme Court has increasingly been granting certiorari to a number of patent cases that have been resulting in important precedent and implications for the future of U.S. patent law. By using Supreme Court as well as federal district court decisions to set more clear standards regarding ambiguities and problems with the current patent system, companies are able to gain a clearer picture of the system in which they are working and loopholes traditionally used by NPEs acting as trolls are being filled. 
As these decisions become engrained into regular patent practice, trolling entities will be faced with additional barriers which, admittedly, may result in increased sophistication of some entities, but may also cause a number of entities to decide that the ever-increasing costs and everdecreasing returns from litigation make the business no longer financially attractive. The guidance provided by the judicial system will be most effective if it continues takes into account the circumstances of the particular entities and remains loyal to the basis of the U.S. patent system: innovation. By ruling in favor of entities that foster innovation, development and production, patents will have the ability to maintain value as tools of development. 